\title{
PENINGKATAN HASIL BELAJAR MELEMPAR BOLA PADA MASA COVID - 19 PADA PERMAINAN BOLA KASTI DENGAN PENDEKATAN SCIENTIFIC TEKNIK EXAMPLE NON EXAMPLE PADA SISWA KELAS V SDN 016536 BAGAN ASAHAN T.A.2020/2021
}

\author{
Muhammad Iqbal' ${ }^{1}$, Liliana Puspa Sari² \\ 1,2 Sekolah Tinggi Olahraga dan Kesehatan Bina Guna, Indonesia \\ Email : lili.binaguna@gmail.com
}

\begin{abstract}
ABSTRAK
Tujuan penelitian ini adalah untuk melihat bagaimana peningkatan hasil belajar Melempar Bola Kasti pada masa covid-19 dengan pendekatan scientific teknik example non example pada siswa kelas V SDN 016536 Bagan Asahan Tahun Ajaran 2020/2021. Lokasi penelitian ini dilaksanakan di SDN 016536 Bagan Asahan. Yang menjadi subjek dalam penelitian ini adalah seluruh Siswa Kelas V SDN 016536 Bagan Asahan Tahun Ajaran 2020/2021 yang terdiri dari 30 siswa. Metode dalam penelitian ini adalah metode PTK dengan teknik tes dan pengukuran menggunakan lembaran portofolio. Analisis data dilakukan dengan reduksi data dilakukan dengan cara menyeleksi, menyederhanakan dan mentranformasikan data yang telah disajikan dalam transkip catatan lapangan. Kegiatan reduksi data ini bertujuan untuk melihat kesalahan dan kekurangan siswa dalam pelaksanaan tes, diperoleh 9 siswa (30\%) yang mencapai tingkat ketuntasan belajar, 21 siswa (70\%) belum mencapai tingkat ketuntasan belajar, dengan nilai rata-rata 68,15. Kemudian dilakukan pembelajaran siklus I dengan menerapkan scientific teknik example non example dalam pembelajaran bola kasti siswa pada materi melempar berdasarkan perbaikan dari siklus I diperoleh sudah 27 siswa 90\%) yang telah mencapai tingkat ketuntasan belajar, 3 siswa (10\%) belum mencapai tingkat ketuntasan belajar, dengan nilai rata-rata 73,76. Dalam hal ini dilihat bahwa terjadi peningkatan nilai rata-rata hasil belajar per siklus yaitu sebesar 18,2 dan peningkatan klasikalnya sebesar 27,7\%. Berdasarkan hasil analisis data dapat dikatakan bahwa melalui Pembelajaran dengan menerapkan scientific teknik example non example dalam pembelajaran melempar bola kasti pada Siswa kelas V SDN 016536016536 Bagan Asahan meningkat. Dalam artian pembelajaran dengan scientific Teknik example non example mempengaruhi hasil belajar melempar bola kasti siswa.
\end{abstract}

\section{Kata kunci: Peningkatan, Melempar Permainan Bola Kasti}

\begin{abstract}
The purpose of this research is to see how the improvement of learning outcomes of baseball throwing during the covid-19 period with a scientific approach to the example non-example technique for fifth grade students at SDN 016536 Asahan Chart for the 2020/2021 Academic Year. The location of this research was carried out at SDN 016536 Bagan Asahan. The subjects in this study were all Grade V students of SDN 016536 Asahan Chart for the 2020/2021 Academic Year which consisted of 30 students. The method in this study is the CAR method with test and measurement techniques using portfolio sheets. Data analysis was carried out by data reduction by selecting, simplifying and transforming the data that had
\end{abstract}


been presented in the transcript of the field notes. This data reduction activity aims to see the mistakes and shortcomings of students in the implementation of the test, obtained 9 students $(30 \%)$ who reached the level of mastery learning, 21 students $(70 \%)$ have not reached the level of completeness of learning, with an average value of 68.15 . Then the first cycle of learning was carried out by applying scientific example non-example techniques in learning baseball students on throwing material based on improvements from the first cycle, it was obtained that 27 students $90 \%$ ) had reached the level of mastery learning, 3 students $(10 \%)$ had not reached the level of mastery learning, with an average value of 73.76. In this case, it is seen that there is an increase in the average value of learning outcomes per cycle which is 18.2 and the classical increase is $27.7 \%$. Based on the results of data analysis, it can be said that through learning by applying scientific example non-example techniques in learning to throw baseball in class V SDN 016536016536 Asahan Charts increased. In the sense of learning with scientific examples non-example techniques affect students' learning outcomes to throw baseballs.

\section{Keywords: Problem Based Learning Method, Forehand lob}

\section{PENDAHULUAN}

Tujuan pendidikan adalah untuk mewujudkan dan mengarahkan siswa agar mampu berkembang sesuai dengan kapasitas yang dimiliki maupun bakat dan prestasi yang ada untuk pembentukan kepribadian yang utuh, memiliki rasa tanggung jawab yang tinggi dan mandiri.Dengan demikian diharapkan siswa memiliki kepribadian yang dinamis, kreatif, inovatif, dengan tidak meninggalkan kebudayaan bangsa sendiri.

Untuk dapat meningkatkan kualitas manusia Indonesia melalui pendidikan, maka peserta didik dituntut untuk selalu bekerja keras, sehingga diharapkan mereka akan memperoleh hasil belajar yang baik dan memuaskan. Salah satu upaya peningkatan sumber daya manusia adalah melalui usaha pendidikan, termasuk pendidikan jasmani. Pada kenyataannya, pendidikan jasmani adalah suatu bidang kajian yang sungguh luas.Titik perhatiannya adalah peningkatan gerak manusia. Lebih khusus lagi, penjas berkaitan dengan hubungan antara gerak manusia dan wilayah pendidikan lainnya: hubungan dari perkembangan tubuh-fisik dengan pikiran dan jiwanya. Fokusnya pada pengaruh perkembangan fisik terhadap wilayah pertumbuhan dan perkembangan aspek lain dari manusia itulah yang menjadikannya unik. Tidak ada bidang tunggal lainnya seperti pendidikan jasmani yang berkepentingan dengan perkembangan total manusia.Pendidikan jasmani diartikan dengan berbagai ungkapan dan kalimat. Namun esensinya sama, yang jika disimpulkan bermakna jelas, bahwa pendidikan jasmani memanfaatkan alat fisik untuk pengembangan keutuhan manusia. Dalam kaitan ini diartikan bahwa melalui fisik, aspek mental dan emosional pun turut terkembangkan, bahkan dengan penekanan yang cukup dalam. Berbeda dengan bidang lain, misalnya pendidikan moral, yang penekanannya benar-benar pada perkembangan moral, tetapi aspek fisik tidak turut terkembangkan, baik langsung maupun secara tidak langsung. Karena hasil-hasil kependidikan dari pendidikan jasmani tidak hanya terbatas pada manfaat penyempurnaan fisik atau tubuh semata, definisi penjas tidak hanya menunjuk pada pengertian tradisional dari aktivitas fisik. Kita harus melihat istilah pendidikan jasmani pada bidang yang lebih luas dan lebih abstrak, sebagai satu proses pembentukan kualitas pikiran dan juga tubuh.Pendidikan jasmani adalah suatu kegiatan yang 
didalamnya menekankan aktivitas gerak jasmani serta usaha yang dilakukan secara sadar melalui pendidikan untuk pertumbuhan dan perkembangan siswa untuk tampil sebagai insan yang sehat baik dalam bertindak, tingkah laku, pikiran dan mental. Tujuan dari pendidikan jasmani yaitu mengembangkan keterampilan gerak. Gerak tersebut terbagi tiga yaitu: lokomotor, non lokomotor dan manipulasi.

Berdasarkan hasil observasi dan pengamatan serta wawancara dengan guru penjas kelas V di SDN 016536 Bagan, Asahan peneliti melihat bahwa dalam pelaksanaan kegiatan pembelajaran pendidikan jasmani pada materi permainan Bola Kasti teknik dasar melempar bola siswa kurang dapat melakukan teknik dasar tersebut dengan baik dan merasa kesulitan dalam melakukan teknik dasar tersebut, sehingga hasil belajar yang diperoleh siswa kurang maksimal. Data hasil observasi awal yaitu dari 30 siswa yang memiliki ketuntasan belajar hanya 7 orang (23\%) sedangkan sisanya yaitu 23 orang siswa $(77 \%)$ belum tuntas.

Dalam hal ini peneliti melakukan pendekatan scentific dalam melakukan teknik dasar melempar bola pada permainan Bola kasti , karena menurut peneliti karakter anakanak usia sekolah dasar mudah jenuh, anak-anak usia sekolah dasar masih dalam masa bermain, serta hal ini dapat mengembangkan pengetahuan siswa dan menyenangkan sehingga dengan terbiasanya siswa dalam mengeksplor pengetahuan dalam permainan tersebut maka siswa dapat dengan mudah melakukan teknik dasar melempar bola dalam permainan Bola Kasti sehingga hasil pembelajaran dapat tercapai seperti yang diharapkan.

\section{METODE PENELITIAN}

Penelitian yang dilaksanakan merupakan Penelitian Tindakan Kelas (PTK) oleh siswa kelas V SDN 016536, Bagan Asahan T.A. 2019/2020 terhadap materi yang dilakukan dengan 2 kali pertemuan pada tanggal 15 dan 20 Mei 2020. Pelaksanaan PTK dilakukan dengan menggunakan pendekatan scientific teknik example non example yaitu gaya mengajar secara aktif mengetahui konsep, hukum atau prinsip melalui tahapan-tahapan mengamati (untuk mengidentifikasi atau menemukan masalah), merumuskan masalah, mengajukan atau merumuskan hipotesis, mengumpulkan data dengan berbagai teknik, menganalisis data, menarik kesimpulan dan mengomunikasikan konsep, hukum atau prinsip yang "ditemukan".

Kognitif adalah penilaian hasil belajar pengetahuan dalam mempelajari materi bola kasti. Prosedur penilaiannya adalah dengan memberikan butir-butir pertanyaan kepada siswa untuk di jawab dalam waktu maksimal 15 menit sampai

30 menit.

Tabel 1. Kategori Penilaian Kognitif

\begin{tabular}{|l|c|c|}
\hline No & Skor & Kategori \\
\hline 1. & $91-100$ & Sangat Baik \\
\hline 2. & $80-90$ & Baik \\
\hline 3. & $75-79$ & Cukup \\
\hline 4. & $60-74$ & Kurang \\
\hline 5. & Kurang dari 60 & Sangat Kurang \\
\hline
\end{tabular}


Pelaksanaan pembelajaran daring materi aktivitas fisik dilaksanakan sejak 13 Mei 2020 hingga 30 Mei 2020 karena adanya pademi corona virus desease 2019 atau di kenal Covid-19. Materi yang disampaikan guru diberikan melalui aplikasi zoom dengan memberikan penjelasan terhadap materi aktivitas fisik.

Penelitian yang dilaksanakan secara virtual atau dalam jaringan (daring) sehingga perkembangan mengenai pembelajaran seutuhnya tidak dapat dilakukan secara langsung terkait perubahan-perubahan yang terjadi. Pada pertemuan materi kelas V SDN 016536, Bagan Asahan penerapan pembelajaran diterapkan secara terbatas atau tidak sesuai dengan waktu yang ditetapkan sebelum Covid-19, yaitu 40 menit/jam.

Pada masa Covid-19 disesuaikan dengan kemampuan siswa yaitu 10-40 menit per satu kali pertemuan. Berdasarkan waktu pelaksaan pembelajaran tersebut maka disimpulan pencapaian kompetensi siswa akan sulit diperoleh dan diperlukan pertemuan lebih lanjut yang lebih intensif.

Hasil capaian belajar siswa selanjutnya diterapkan setelah pemberian materi yakni dihari kedua, hal ini dikarenakan waktu pembelajaran pada satu materi tidak dapat diterapkan dalam jangka waktu yang lama mengigat sekolah memberikan batasan pertemuan, sedangkan materi yang telah ditetapkan dalam satu semeter harus dicapai sesuai kalender akademik masa Covid-19. Data penelitian yang diperoleh pada kegiatan penelitian adalah hasil penilaian mulai dari pertemuan 1 (satu) hingga pertemuan 2 (dua). Berikut data penelitian yang diperoleh dalam tabel berikut :

Tabel 4.1. Data Penelitian

\begin{tabular}{|c|c|c|c|c|c|c|c|}
\hline No & $\begin{array}{c}\text { Hasil } \\
\text { Tes }\end{array}$ & $\begin{array}{c}\text { Jumlah } \\
\text { Siswa } \\
\text { Yang } \\
\text { Tuntas }\end{array}$ & Persentase & $\begin{array}{c}\text { Jumlah } \\
\text { Siswa } \\
\text { Yang } \\
\text { Tidak } \\
\text { Tuntas }\end{array}$ & Persentase & $\begin{array}{c}\text { Nilai } \\
\text { Rata- } \\
\text { rata }\end{array}$ & $\begin{array}{c}\text { Keterangan } \\
\text { Klasikal }\end{array}$ \\
\hline 1 & Awal & 9 & $23 \%$ & 21 & $77 \%$ & 67,2 & $\begin{array}{c}\text { Belum } \\
\text { Tuntas }\end{array}$ \\
\hline 2 & $\begin{array}{c}\text { Tes } \\
\text { Siklus } \\
\text { I }\end{array}$ & 27 & $90 \%$ & 3 & $10 \%$ & 80,6 & Tuntas \\
\hline
\end{tabular}

Data penelitian diketahui siswa kelas V SDN 016536 dengan jumlah siswa 30 orang yang menjadi subyek penelitian diperoleh data 9 siswa (23\%) memiliki ketuntasan belajar dan 21 siswa (77\%) siswa belum memiliki ketuntasan dalam belajar. Pelaksanan penelitian tindakan kelas pada siklus I diperoleh data 3 siswa (9\%) tuntas belajar dan 27 siswa (91\%) belum tuntas belajar.

\section{KESIMPULAN}

Penelitian yang telah dilaksanakn merupakan Penelitian Tindakan Kelas (PTK) yang dilakukan pada siswa kelas V SDN 016536, Bagan Asahan T.A. 2019/202. Masa Covid-19 terdapat peningkatan pada hasil belajar aktiviats fisik melalui pendekatan scientific teknik example non example. Peningkatan terjadi dengan menggunakan satu 
siklus diantaranya siklus memiliki persentase kelulusan klasikal siswa melampaui KKM 70 adalah 90\%. Keberhasilan pembelajaran ditinjau dari perbandingan standar kelulusan klasikal pembelajaran PJOK yang telah ditentukan sekolah dengan pencapaian pembelajaran yang dilakukan melalui pengukuran hasil belajar.

\section{DAFTAR PUSTAKA}

Ahmad Al Munawar, \& Fajar Mugo Raharjo. (2020). The Effect Of Paired Training On The Down Passing Skill Of Volleyball In Madrasa Aliyah Uinsu Laboratory 2019. Jurnal Ilmiah STOK Bina Guna Medan,2(1), 7-12. Retrieved from https://jurnal.stokbinaguna.ac.id/index.php/JSBG/article/view/87

Aprial M, B. (2014). PENERAPAN MODEL PEMBELAJARAN BERBASIS MASALAH (PROBLEM BASED LEARNING) DENGAN PENDEKATAN SCIENTIFIC DALAM UPAYA MENINGKATKAN HASIL BELAJAR CHEST PASS DALAM PERMAINAN BOLA BASKET SISWA KELAS X SMA NEGERI 5 TANJUNG BALAI TAHUN AJARAN 2014/2015 (Doctoral dissertation, UNIMED).

Boby Helmi, Ramadan, \& Dicky Hendrawan. (2020). Impact of Teaching Style and Arm Muscle Strength on Bulletproof Learning Outcomes.JPJ (Jurnal Pendidikan Jasmani), 1(1), 24-28. Retrieved from https://jurnal.stokbinaguna.ac.id/index.php/IPI/article/view/110

Hendra Jondry Hiskya, Hasanudin Jayawardana. (2019). Peningkatan Kualitas Pelatihan Bulu Tangkis Dengan Model Crowdfunding Di Merauke Perbatasan Ri-Png. Tadulako Journal Sport Sciences And Physical Education, 7(2). 1-10

Herman Herman. (2019). Kontribusi Koordinasi Mata Tangan, Kelentukan Pergelangan Tangan dan Keseimbangan Terhadap Kemampuan Untuk Servis Panjang dalam Permainan Bulutangkis Pada Siswa. SPORTIVE: Journal Of Physical Education, Sport and Recreation. 2(2), 101-113. 10.26858/sportive.v2i2.9889Munawar, A. A., \& Hendrawan, D. (2019). Pengembangan Media Pembelajaran Interaktif Berbasis Multimedia Pada Mata Kuliah Pembelajaran Sepak Bola. Jurnal Ilmiah STOK Bina Guna Medan, 1(1), 62-69. $\quad$ Retrieved https://jurnal.stokbinaguna.ac.id/index.php/JSBG/article/view/15

Ilham Kamaruddin. (2019). Pengaruh Kemampuan Fisik Terhadap Keterampilan smash Dalam Permainan Bulutangkis. SPORTIVE: Journal Of Physical Education, Sport and Recreation. 2(2), 144-127. 10.26858/sportive.v2i2.10949

Karo Karo, A. A. P., M, B. A., Sari, I. E. P., Sihombing, H., \& Sari, L. P. (2020). Effect of playing methods on the Dribble Ability of the Football Game. Kinestetik: Jurnal Ilmiah Pendidikan Jasmani, 4(2), 158-163. https://doi.org/10.33369/ik.v4i2.12566

Pradipta, D., Nugraha, T., \& Kasih, I. (2019). Studi Eksperimen Tentang Model Pembelajaran Dan Motivasi Belajar Terhadap Hasil Belajar Bulutangkis Servis Pendek Backhand 
Pada Siswa Sma Nurul Hasanah. Jurnal Pedagogik Olahraga, 5(1), 12-21. doi:https://doi.org/10.22245/jpor.v5i1.14484

Sinulingga, Albadi, E. (2016). Perbedaan Pengaruh Latihan Double Leg Bound Dan Latihan Alternate Leg Bound Terhadap Kecepatan Tendangan Maegeri Chudan Dan Power Otot Tungkai Pada Atlet Putra Umur 14 - 16. Jurnal Pedagogik Olahraga, 2(1), 56-76. doi:https://doi.org/10.22245/jpor.v2i1.4509 